\title{
Efficiency of Some Bioagents and Potassium Humate in Controlling Tomato wilt Disease caused by Fusarium Oxysporum f.sp. Lycopersici
}

\author{
* Mona F. Ahmed; ${ }^{* *}$ Nawal A. Eisa; ** Gehad M. El-Habbaa; ${ }^{* *}$ Ibrahim A. I. El-Fiki and *Seham M. Ragab \\ *Plant Pathol. Res. Inst., Agric. Res. Center, Giza, Egypt. \\ **Plant pathol. Dept., Fac. Agric., Benha Univ., Egypt. \\ Corresponding author: monafahim78@gmail.com
}

\begin{abstract}
Fusarium oxysporum f.sp. lycopersici (FOL) is one of the most important fungi causing vascular wilt disease of tomato plants. Many different agents i.e., Bacillus subtilis, Trichoderma harzianum, T. viride, alga (Sparulina platensis), Mycorrhiza (Glomus sp.) and potassium humate were investigated for their antagonistic effects on the growth of FOL in vitro. T. harzianum and potassium humate were the most effective treatments, followed by B. subtilis and alga extract. The previously mentioned treatments were studied under greenhouse conditions and natural infection in the field. T. harzianum and potassium humate were the most effective treatments against FOL followed by $B$. subtilis and alga extract. Mycrrohiza was the lowest effect treatment under greenhouse and field conditions. T. harzianum and potassium humate decreased the activities of hydrolyzing enzymes and increased all of total phenols and plant parameters (fresh, dry weight and length/ plant) of treated tomato plants.
\end{abstract}

Keywords: F. oxysporum, Tomato plants, Biological agents, potassium humate, hydrolyzing enzymes, phenols, growth parameters of the plants.

\section{Introduction}

Tomato, (Solanum lycopersicum L.), is known as one of the most important vegetable crops worldwide. It has been reported that it could be infect by many pathogens like $F$. oxysporum f. sp. lycopersici (FOL), F. solani, F. semitectum, Rhizoctonia solani, Verticillium albo-atrum, Microphomina phaseolina. F. oxysporum is a soil borne fungal pathogen that attacks plants through roots at all stages of plant growth (Hirano and Arie, 2006). It causes major economic losses by inducing necrosis and wilting symptoms in many crop plants (Cotxarrena et al., 2002).

Many studies have been carried out to find more convenient alternatives and environmentally safer methods than using fungicides to control plant diseases (Singh and Prithiviraj, 1997, Paul and Sharma, 2002 and Agbevin et al., 2004). Using the antifungal plant products has been proven to be an efficient solution in controlling many plant diseases. Also, in vitro using of microbial antagonists significantly reduced seed infection caused by Fusarium oxysporum (Sultana and Ghaffar, 2013). Trichoderma harzianum, T. asperellum, and T. virens affect tomato wilt disease under greenhouse conditions where they caused $80-87 \%$ inhibition of F. oxysporum compared to the control (Mohammad and Zohreh, 2015). It has been reported that Trichoderma spp. (28 isolates) confer plant protection against tomato wilt and promote growth of tomato plants under in vitro and in vivo conditions. In vitro, $T$. harzianum $(\mathrm{N}-8)$ inhibited the radial mycelia growth of the tested pathogen effectively. Also, the same isolate caused the least disease incidence while, in vivo, T. harzianum followed by $T$. viride and Bacillus subtilis caused the maximum reduction in seedling and root infections (Sultana and Ghaffar, 2013 and Barari, 2016,).

Abdel-Monaim et al., (2014) reported that potassium humate and alga (Sparulina platensis) increased plant growth parameters (plant height and number of branches). Also, using extracts of Sparulina platensis, as chemical fertilizer in view of a sustainable agriculture was safe to the environment, human and animal health (Aghofach et al., 2015).

The objective of this study is to evaluate the potential of different bioagents and natural products for reducing the severity of Fusarium wilt of tomato in vitro and in vivo.

\section{Materials and Methods}

Isolation, identification and pathogenicity test:

Tomato plants showing typical symptoms of the Fusarium wilt disease were collected from different tomato locations in nine governorates in Egypt (Ismailia, Bani-Sweif, Beheira, Giza, Damietta, Fayum, Sharkiya, Qalyubia, and Minia) during autumn, winter and spring of growing seasons 2012 and 2013. Cuttings ( $3 \mathrm{~cm}$ length) from the stem of tomato plants above the crown area revealing different degrees of vascular discoloration were used for isolation of the wilt fungus (Katan et al., 1991 and Amini, 2009). The growing fungi were purified using the hyphal tip technique (Nelson, 1983). Then, the purified fungal isolates were identified through morphological investigation as reported previously by Barnett and Hunter, (1998) at Department of 
Mycology and Fungi Disease Survey Research. Plant Pathology Institute, ARC, Giza, Egypt.

Pathogenicity test and Koch's postulates were carried out successfully for each isolate on tomato seedlings (Super Strain B hybrid) in pots $(20 \mathrm{~cm} \varnothing)$ using sand corn inoculum under greenhouse conditions to confirm their virulence and then the reisolated pure cultures of FOL were maintained on PDA slants at $4^{\circ} \mathrm{C}$. The highest virulent FOL isolate was used for the next trails. Pathogenicity test was carried out under greenhouse conditions of the Plant Pathology Institute, Agricultural Research Center (ARC), Giza, Egypt.

\section{Control of FOL fungus in vitro \\ 1-Effect of potassium humate and alga extract on FOL growth.}

During this experiment, the tested commercial potassium humate and alga (Sparulina platensis) were screened against highest virulent FOL isolate in vitro during pathogenicity test as mentioned above. The tested commercial potassium humate was obtained kindly from the Agricultural Wastes Training Center, Moshtohor, Qalyubia Governorate, while, the tested alga (S. platensis) was obtained kindly from Microbiology Dept. Soil, Water and Environment Research Institute Agricultural, Research Center, Giza, Egypt.

Potato dextrose agar medium (PDA) was used in the experiment. The antifungal activity of tested treatments accomplished on PDA plates $(90 \mathrm{~mm} \varnothing)$. Each of humate or alga was tested at concentrations of $1,2,3,4$, and $5 \%$ by adding $1,2,3,4$ and $5 \mathrm{~mL}$ of humate solution or alga extract to $99,98,97,96$ and $95 \mathrm{~mL}$ of melted PDA medium, respectively, to be the final tested concentrations, then poured into Petri dishes in triplicates. After solidification, a disc (3 $\mathrm{mm} \varnothing)$ of the tested FOL isolate was placed in the center of each plate. PDA plates treated with Topsin M70 fungicide ( $700 \mu \mathrm{g} / \mathrm{L}$ medium) served as treated control while, the inoculated plates with FOL agar disc only on the center of the plate served as untreated control. All plates were incubated at $28^{\circ} \mathrm{C}$ for 7-10 days, then the reduction percentage was calculated as the following using the formula suggested by Sirirat et al., (2009).

Reduction Percentage $=\left(\frac{\mathrm{de}-\mathrm{di}}{\mathrm{de}}\right) \times 100$
Where, de = mean diameter of growth in control; di= mean diameter of growth in treatment.

\section{2-Effect of Trichoderma harzianum, T. viride and Bacillus subtilis on FOL growth.}

In this experiment, the effect of some bioagents i.e., T. harzianum, T. viride and B. subtilis (obtained kindly from the Mycology Research and Disease Survey Department, Plant Pathology Institute, ARC, Giza, Egypt) were investigated for their antagonistic effects on the growth of the same highest virulent FOL isolate in vitro as mentioned above. Dual culture technique was used for in vitro evaluation against the tested FOL isolate. PDA medium was used in this experiment. The antifungal activity of tested treatments accomplished on PDA plates (90 mmØ). PDA medium was poured into Petri dishes, after solidification, a disc ( $3 \mathrm{~mm} \emptyset)$ of each one of the tested Trichoderma isolates was placed in one side of each plate. At the same time, a disc ( $3 \mathrm{~mm} \varnothing)$ of the tested FOL isolate was placed in the opposite side of the plate. B. subtilis was inoculated by streaking onto one side of the prepared Petri dishes and at the same time another disc $(3 \mathrm{~mm} \varnothing)$ of the pathogen was placed in the opposite side. Each Treatment was replicated three times. On the other hand, PDA plates treated with Topsin M70 fungicide $(700 \mu \mathrm{g} / \mathrm{L}$ medium) served as treated control while, the inoculated plates with FOL agar disc only on the center of the plate served as un-treated control. The plates were incubated at $28^{\circ} \mathrm{C}$ for $7-10$ days then the growth reduction was calculated as mentioned above.

\section{Control of FOL fungus in vivo 1-Greehouse experiment}

The present experiment was carried out on tomato plants (Super Strain B hybrid) in pots (20 cmØ) under greenhouse conditions at Plant Pathology Research Institute Agricultural Research Center Giza, Egypt, during the two successive growing seasons 2014-2015 and 2015-2016. In this experiment, the antagonistic effects of $T$. harzianum, T. viride, B. subtilis, alga (S. platensis), mycorrhiza (Glomus sp.), potassium humate and the fungicide Topsin M70 were investigated against the tested FOL isolate as following:

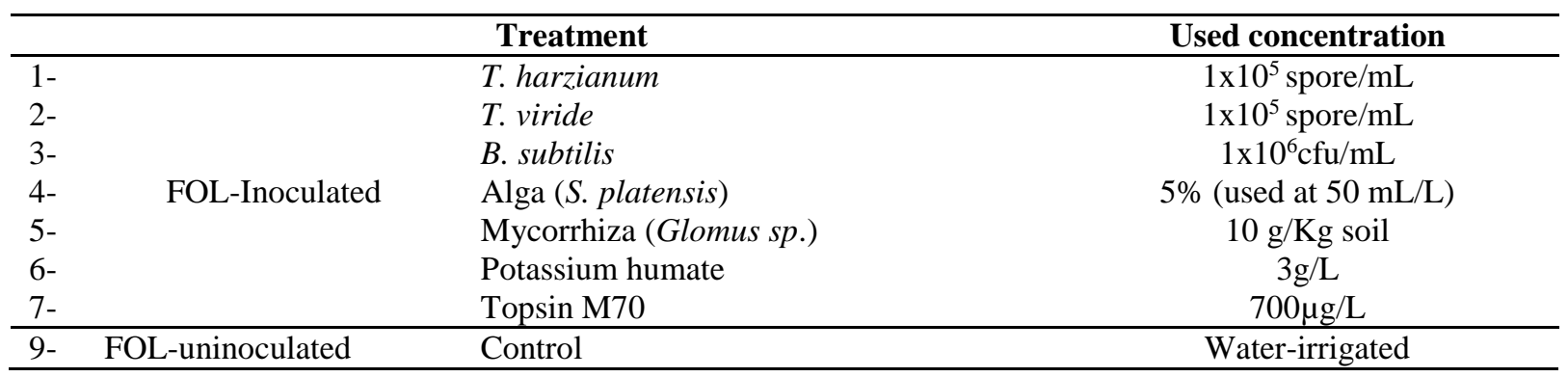


Mycorrhiza (Glomus sp.) was used as recommended by Mycology and Fungi Disease Survey Research Department, Plant Pathology Institute, ARC, Giza, Egypt. All treatments were applied as root immersion for $20 \mathrm{~min}$. The experimental treatments were done in randomized complete block design with four replicates (pots). The second treatments were carried out one month after the first treatment with soil drainage.

\section{Preparation the inocula of tested bioagents:}

The antagonistic bacterium (B. subtilis) was grown on nutrient broth medium (Abd-Alla et al., 2007). The bacterial isolate was incubated in a rotary shaker at 200 rpm for $48 \mathrm{~h}$ at $28 \pm 2{ }^{\circ} \mathrm{C}$. The bacterial cells were harvested by centrifugation at $6000 \mathrm{rpm}$ for $10 \mathrm{~min}$, washed twice with $0.05 \mathrm{M}$ phosphate buffer at $\mathrm{pH} 7.0$ and re-suspended in sterilized distilled water. The concentration of bacteria was adjusted to approximately $10^{6} \mathrm{cfu} / \mathrm{ml}$ using turbidity meter as mentioned by (Abdel-Kader et al., 2012). Meanwhile, the antagonistic fungi were grown on PDA medium and incubated for ten days at $25 \pm 2{ }^{\circ} \mathrm{C}$. Fungal conidia and mycelium were harvested by scraping the surface of the colonies with a spatula and transferred to sterilized distilled water and filtered through nylon mesh, and then spore suspension was adjusted approximately to $10^{5}$ spore $/ \mathrm{mL}$ with the aid of a haemacytometer slide, (Abd-Alla et al., 2007).

Preparation the inocula of alga and mycorrhiza:

Alga treatment was prepared for application at rate $50 \mathrm{~mL}$ alga extract/L water $(5 \%)$, meanwhile, mycorrhiza (Glomus. sp.) treatment was prepared for application at rate $10 \mathrm{~g}$. $/ \mathrm{kg}$ soil.

\section{Preparation of Potassium Humate solution:}

Potassium humate solution was prepared for application at rate $3 \mathrm{~g}$ potassium humate/ $\mathrm{L}$ water.

\section{Preparation of FOL inoculum:}

The inoculum of FOL was prepared as mentioned above in pathogenicity test as following:

The tested fungal isolate was inoculated into autoclaved sand corn medium $(25 \mathrm{~g}$ clean sand and $75 \mathrm{~g}$ corn covered by enough tap water in $500 \mathrm{~mL}$ bottles). The pots $(20 \mathrm{~cm} \varnothing)$ were filled by $2 \mathrm{Kg}$ of sterilized soil and infested by the prepared inoculum at rate of $3 \%$ of soil weight then irrigated regularly for one week before treating with the different treatments and then transplanting the seedlings (4 weeks old of Super Strain B hybrid). Each treatment was replicated 4 times and 4 seedlings were placed in each pot. The control treatment was pots filled by the same soil and inoculated with FOL only.

\section{2-Field experiment}

In this trail, tomato plants (Super Strain B hybrid), naturally infected with Fusarium wilt disease under open field conditions at EL-Khanka region, Qalyubia Governorate during the summer growing season 2017 were used. The treatments were arranged in randomized complete block design with three replicates (plots). Each experimental plot included 4 ridges, each one $70 \mathrm{~cm}$ wide and $5 \mathrm{~m}$ long. Plot area was $10.5 \mathrm{~m}^{2}$. At the $1^{\text {st }}$ of May, transplanting of thirty-days old of tomato seedlings (Super Strain B hybrid) took place in one side of the ridge in the presence of water at $30 \mathrm{~cm}$ a part and each plot contained 27 plants. All agronomic practices endorsed by Ministry of Agriculture, Egypt were carriedout for cultivation of tomato plants, except fungicide application practices. This experiment aimed to evaluate the best-chosen treatments which have inhibitory effects on the fusarium wilt pathogen (FOL) in vivo. Treatments were applied individually as root immersion as following: T. harzianum (at $10^{5} \mathrm{cfu} / \mathrm{mL}$ ), B. subtilis (at $10^{6} \mathrm{cfu} / \mathrm{mL}$ ), potassium humate (at $\left.3 \mathrm{~g} / \mathrm{L}\right)$, alga $(S$. platensis at 5\%), and mycorrhiza (Glomus sp.) at $10 \mathrm{~g} / \mathrm{Kg}$ soil and the fungicide (Topsin M70) at recommended dose $700 \mu \mathrm{g} / \mathrm{L}$. Plants sprayed with water used as control.

\section{Disease assessments and some vegetative parameters}

Two months post transplanting of tomato plants, disease incidence and disease severity percentage were recorded. Also, fresh weight/plant (g.), dry weight/plant (g.) and plant length (cm.) were recorded for each treatment of greenhouse and field trails. Disease incidence (DI\%) was calculated and expressed in percentage scale by using the following formula: DI\% $=(\mathrm{D} / \mathrm{T}) \mathrm{X} 100$, where, $(\mathrm{D})=$ Number of diseased plants; $(\mathrm{T})=$ Total observed plants. For assessing disease severity, ascertained number of plants were selected randomly in each replication (plot) to estimate disease severity individually for each one using 0-5 rating scale as described by Xiao and Subbarao, (1998) where, $0=$ no discoloration, $1=1$ to $10 \%$ discoloration, $2=11$ to $30 \%$ discoloration, $3=31$ to $50 \%$ discoloration, $4=51$ to $75 \%$ discoloration and $5=76 \%$ to $100 \%$ discoloration. Fusarium wilt disease severity\% was assessed according to the following formula: Disease severity $\%=\Sigma(\mathrm{n} \mathrm{X} \mathrm{v)} / 5 \mathrm{~N}) \times 100$, where, $(\mathrm{n})=$ Number of plants in each category; $(\mathrm{v})=$ Numerical values of symptoms category; $(\mathrm{N})=$ Total number of plants; (5) = Maximum numerical value of symptom category. Efficacy $(\mathrm{Ef} \%)$ percentage of different treatments was calculated based on mean of disease incidence and disease severity percentage. Efficacy\% was calculated for comparing between all tested treatments with untreated control as follows:

Ef \% $=$ control - treatment $/$ control X 100.

\section{Biochemical Studies \\ 1- Enzymatic Activity}

Two months post transplanting of tomato plants, samples representing the whole plant were taken from each treatment for determining phenolic compounds (conjugated, free and total phenol), 
cellulose $(\mathrm{CX})$, polygalacturonase $(\mathrm{PG})$ percentages assessments.

For phenolic contents determination, whole fresh plant samples were extracted separately using the suggested method of Aneja, (2001). Phenolic compounds were calculated for each treatment as milligrams of catechol/g fresh weight of leaves. The developed color was measured at $520 \mathrm{~nm}$ using spectrophotometer against a reagent blank.

For enzymatic determinations, the crude leaf enzyme extract was prepared as recommended by Aneja, (2001). Crude leaf extract was prepared by homogenizing 50 grams of each treatment with 50 $\mathrm{mL}$ of distilled water, then filtrated through two layers of cheese cloth and centrifuged at $3000 \mathrm{rpm}$ for 10 minutes. The clear supernatant was used to estimate the pectolytic and cellulolytic enzymes activity. CX activity determination was measured using viscosity method described by Aneja, (2001) as follows: $1.2 \%$ carboxy methyl cellulose (CMC) substrate was added into phosphate buffer solution at $\mathrm{pH} 5.6$ then $2.5 \mathrm{~mL}$ of the crude enzyme sample was added to $5 \mathrm{~mL}$ buffer and incubated at $30^{\circ} \mathrm{C}$. Viscosity of the reaction mixture was estimated before incubation (zero time), and after 30 minutes incubation. Loss in viscosity was calculated according to this formula:

$\mathrm{T} 0-\mathrm{T} 1 / \mathrm{T} 0-\mathrm{Tw} \mathrm{X} 100$, where, $\mathrm{T} 0=$ the time of flow in seconds of the treated mixture at zero time; $\mathrm{T} 1=$ the time of flow at a given time interval and $\mathrm{Tw}$ $=$ the time of flow at distilled water.

Concerning PG activity determination, 1.2\% pectin substrate was added to phosphate buffer solution at $\mathrm{pH} 5.6$ then $2.5 \mathrm{~mL}$ of the crude enzyme sample was added to $5 \mathrm{~mL}$ buffer and incubated at $30^{\circ} \mathrm{C}$. Viscosity of the reaction mixture was estimated before incubation (zero time), and after 30 minutes incubation as mentioned before in $\mathrm{CX}$ activity determination.

\section{Statistical analysis}

All data were subjected to the proper statistical analysis using the MSTAT statistical software and comparison was made following fishers L.S.D. (0.05). (Gomez and Gomez, 1984).

\section{Results and Discussion}

Isolation of Fusarium wilt pathogen and frequency of isolated microorganisms:

Results in Table (1) indicate that Fusarium oxysporum was the most frequently isolated fungus. It was isolated from all the nine governorates. Fayum isolate showed the highest frequency rate $(73.7 \%)$ followed by Beheira (70\%), Sharkiya $(66.7 \%)$, BaniSweif (57.8\%), Qalyubia (55.6\%), Ismailia (53\%), Minia $(47.4 \%)$ and Damietta $(41.7 \%)$ meanwhile, Giza show the least frequency $(37.5 \%)$. On the other hand, Microphomina phasolina was the lowest frequency rate in Damietta $(8.2 \%)$ followed by Qalyubia (5.5\%), Minia and Bani-Sweif (5.3\%), Fayum (4.4\%), Sharkiya, Beheira, Giza and Ismailia $(0.0 \%)$. Selim and Zanaty, (2014) isolated Fusarium oxysporum from five different governorates in the Nile Delta. Four governorates within the Delta in addition to Ismailia in the east were chosen. Fusarium isolates were obtained from the stem of naturally infected tomato plants. Another scientists isolated Fusarium oxysporum f. sp. lycopersici Akram et al., (2014), Priyanka et al., (2014), Narendra and Swati, (2015) Barari, (2016) and Mohammed et al., (2016).

Table 1. Isolation of tomato fusarium wilt pathogen and frequency of isolated microorganisms.

\begin{tabular}{|c|c|c|c|c|c|c|c|c|c|c|c|c|c|c|c|c|c|c|}
\hline \multirow{3}{*}{$\begin{array}{c}\text { Isolated } \\
\text { microorganism }\end{array}$} & \multicolumn{18}{|c|}{ Isolation localities } \\
\hline & \multicolumn{2}{|c|}{ Ismailia } & \multicolumn{2}{|c|}{ Bani Sweif } & \multicolumn{2}{|c|}{ Beheira } & \multicolumn{2}{|c|}{ Giza } & \multicolumn{2}{|c|}{ Damietta } & \multicolumn{2}{|c|}{ Fayum } & \multicolumn{2}{|c|}{ Sharkiya } & \multicolumn{2}{|c|}{ Qalyubia } & \multicolumn{2}{|c|}{ Minia } \\
\hline & $\mathrm{Fr}$ & $\%$ & $\mathrm{Fr}$ & $\%$ & Fr & $\%$ & Fr & $\%$ & $\mathrm{Fr}$ & $\%$ & $\mathrm{Fr}$ & $\%$ & $\mathrm{Fr}$ & $\%$ & Fr & $\%$ & Fr & $\%$ \\
\hline F. oxysporum & 9 & 53.0 & 11 & 57.8 & 7 & 70.0 & 3 & 37.5 & 5 & 41.7 & 17 & 73.8 & 4 & 66.7 & 10 & 55.6 & 9 & 47.7 \\
\hline F. solani & 4 & 23.5 & 1 & 5.3 & 1 & 10.0 & 1 & 12.5 & 0 & 0.0 & 2 & 8.7 & 0 & 0.0 & 2 & 11.1 & 2 & 10.5 \\
\hline F. semitectum & 0 & 0.0 & 2 & 10.5 & 0 & 0.0 & 0 & 0.0 & 2 & 16.7 & 0 & 0.0 & 0 & 0.0 & 2 & 11.1 & 2 & 10.5 \\
\hline$R$. solani & 4 & 23.5 & 4 & 21.1 & 1 & 10.0 & 1 & 12.5 & 2 & 16.7 & 2 & 8.7 & 1 & 60.6 & 3 & 16.7 & 5 & 26.3 \\
\hline V. albo-atrum & 0 & 0.0 & 0 & 0.0 & 1 & 10.0 & 3 & 37.5 & 2 & 16.7 & 1 & 4.4 & 1 & 60.7 & 0 & 0.0 & 0 & 0.0 \\
\hline M. phaseolina & 0 & 0.0 & 1 & 5.3 & 0 & 0.0 & 0 & 0.0 & 1 & 8.2 & 1 & 4.4 & 0 & 0.0 & 1 & 5.5 & 1 & 5.3 \\
\hline Total & 17 & 100 & 19 & 100 & 10 & 100 & 8 & 100 & 12 & 100 & 23 & 100 & 6 & 100 & 18 & 100 & 19 & 100 \\
\hline
\end{tabular}

$\mathrm{Fr}=$ frequancy

\section{1-Pathogenicity test}

Data in Table 1 indicate that, FOL isolate of Sharkiya gave the highest disease severity and disease incidence percentage (39.7 and 68.7\%) respectively, followed by Damietta isolate (25 and $50 \%$ ), then Giza isolate (21.2 and $43.7 \%)$, Beheira isolate (18.7 and 37.5\%), Bani Sweif isolate (17.5 and $31.2 \%)$, Minia isolate (16.2 and 37.5\%), Ismailia isolate (15.0 and $31.2 \%$ ) and Fayum isolate (13.7 and
$25.0 \%$ ). On the other hand, the lowest recorded disease incidence and disease severity were 12.5 and $25.0 \%$ Qalyubia isolate. These results could be discussed in light the findings of Narendra and Swati, (2015) and Barari, (2016) who tested the pathogenicity of the FOL isolates on PKM1 tomato cultivar and determined that the most virulent isolate was FOL (L-8). 
Table 2. Pathogenicity test of FOL isolated from different governorates on tomato plants (Super Strain B hybrid) under greenhouse conditions.

\begin{tabular}{|c|c|c|}
\hline Governorate & Disease incidence \% & Disease severity \% \\
\hline Ismailia & 31.2 & 15.0 \\
\hline Fayum & 25.0 & 13.7 \\
\hline Beheira & 37.5 & 18.7 \\
\hline Bani Sweif & 31.2 & 17.5 \\
\hline Minia & 37.5 & 16.2 \\
\hline Giza & 43.7 & 21.2 \\
\hline Damietta & 50.0 & 25.0 \\
\hline Sharkiya & 68.7 & 39.7 \\
\hline Qalyubia & 25.0 & 12.5 \\
\hline
\end{tabular}

Effect of tested bioagents and potassium humate on growth of FOL in vitro

Data in Table 2 reveal that all tested bioagents i.e., T. harzianum, B. subtilis and S. platensis and potassium humate in addition to Topsin M70 fungicide reduced effectively the radial growth of tested FOL pathogen. Data in the same table reveal that all tested treatments had clear significant inhibitory effects on FOL growth comparing with control treatment. In this respect, $T$. harzianum at $10^{5}$ spore $/ \mathrm{mL}$ gave the highest reduction percentage $(87.7 \%)$ followed by $B$. subtilis at $10^{6} \mathrm{cfu} / \mathrm{mL}$ $(80.0 \%)$ and Trichoderma viride at $10^{5} \mathrm{spore} / \mathrm{mL}$ $(77.7 \%)$, respectively. While, alga extract at $5 \%$ and $4 \%$ gave 74.4 and $64.4 \%$ reduction percentage on pathogen mycelial growth, while, potassium humate gave the lowest reduction percentage $(57.7 \%)$ at the concentrations of 3,4 and $5 \mathrm{~g} / \mathrm{L}$. These results could be discussed in light that $T$. harzianum and B. subtilis could be involved for controlling Fusarium wilt disease on tomato (Abdel-Kader, et al. 2012). On the other hand, Alwathnani and Perveen, (2012) tested some of biological control agents to control wilt disease of tomato incited by FOL in vitro and found that, T. harzianum inhibited the radial colony growth of the tested pathogen. It is well established that, potassium humate had inhibitory effect on radial growth of the pathogen where, it was evaluated for controlling wilt disease caused by $F$. oxysporum f.sp. lycopersici on Super Strain B hybrid and found that potassium humate able to inhibit linear growth of the pathogen (Abdel-Monaim, et al. 2012). Fulvic acid and humic acid potentially suppressed Alternaria alternata and Fusarium cucumarun in PDA medium (Moliszewska and Pisarek, 1996).

Table 3. Effect of tested bioagents and potassium humate on radial growth of FOL In vitro.

\begin{tabular}{llcc}
\hline \multicolumn{1}{c}{ Treatment } & Concentration & Radial mycelial growth $(\mathbf{m m})$ & Reduction \% \\
\hline & $1 \%$ & $85.0 \mathrm{~b}$ & 5.5 \\
Alga extract & $2 \%$ & $56.0 \mathrm{~d}$ & 41.1 \\
(Sparulina platensis) & $3 \%$ & $43.0 \mathrm{e}$ & 52.2 \\
& $4 \%$ & $32.0 \mathrm{~g}$ & 64.4 \\
& $5 \%$ & $23.0 \mathrm{~h}$ & 74.4 \\
& $1 \mathrm{~g} / \mathrm{L}$ & $73.0 \mathrm{c}$ & 18.8 \\
Potassium humate & $2 \mathrm{~g} / \mathrm{L}$ & $70.0 \mathrm{c}$ & 22.2 \\
& $3 \mathrm{~g} / \mathrm{L}$ & $38.0 \mathrm{f}$ & 57.7 \\
B. subtilis & $4 \mathrm{~g} / \mathrm{L}$ & $38.0 \mathrm{f}$ & 57.7 \\
$T$. viride & $5 \mathrm{~g} / \mathrm{L}$ & $38.0 \mathrm{f}$ & 57.7 \\
T. harzianum & $10^{6} \mathrm{cfu} / \mathrm{ml}$ & $18.0 \mathrm{i}$ & 80.0 \\
Topsin M70 & $10^{5} \mathrm{spore} / \mathrm{ml}$ & $20.0 \mathrm{hi}$ & 77.7 \\
Control & $10^{5} \mathrm{spore} / \mathrm{ml}$ & $11.0 \mathrm{j}$ & 87.7 \\
\hline LSD $\mathbf{0 . 0 5}$ & $700 \mu \mathrm{g} / \mathrm{L}$ & $0 \mathrm{k}$ & 99 \\
\hline
\end{tabular}

Effect of tested bioagents and potassium humate on tomato Fusarium wilt disease assessments under greenhouse conditions

Data in Table 4 indicate that all tested biotic and abiotic treatments i.e., T. harzianum $\left(10^{5}\right.$ spore $\left./ \mathrm{mL}\right)$, B. subtilis $\left(10^{6} \mathrm{cfu} / \mathrm{mL}\right), \quad T$. viride $\left(10^{5} \mathrm{spore} / \mathrm{mL}\right)$, potassium humate $(3 \mathrm{~g} / \mathrm{L})$, alga extract (Spirulina platensis) at 5\%, mycrrohiza (Glomus sp.) at $10 \mathrm{~g} / \mathrm{Kg}$ soil and Topsin M70 fungicide at $700 \mu \mathrm{g} / \mathrm{L}$ were able to reduce effectively the infection and disease severity\% of Fusarium wilt disease on tomato Super Strain B hybrid under greenhouse conditions during the two successive growing seasons 2014-2015 and 2015-2016. As shown in the same table, all treatments had clear significant reduction on tomato disease assessments (Fusarium disease severity and disease incidence\%) comparing with the control treatment. In this respect, Topsin M70 gave the 
highest significant reduction of fusarium disease severity and disease incidence $\%$ during the two growing seasons. Topsin M70 followed by $T$. harzianum and potassium humate recorded the highest efficacy\% of disease severity $(96.22,84.89$ and $84.89 \%$, respectively) and disease incidence $\%$ (91.69, 80.95 and $80.95 \%$, respectively). These obtained results confirmed that, Topsin M70 considered good preventive resource for controlling such disease. But, biological agents and potassium humate could be alternatives to the passive use of chemical fertilizers and fungicides in view of a sustainable agriculture that is friendly to the environment, human and animal health. T. harzianum tested as biological control agent to control Fusarium wilt of tomato under greenhouse conditions. These results are in harmony with those obtained by Alwathnani and Perveen, (2012) where, $T$. harzianum showed seed germination enhancement by $80 \%$ and enhanced plant growth parameters significantly in all treatments. Sultana and Ghaffar, (2013) reported in vivo that the maximum reduction in seedling and root infection was observed with $T$. harzianum treatment followed by $T$. viride and $B$. subtilis. Concerning alga (Spirulina platensis), Aghofach et al., (2015) mentioned that extracts or powder of $S$. platensis were the most effective in improving tomato plant growth and development parameters. Also, Layam et al., (2016) used $S$. platensis as a bio-fortification agent in light the role of zinc and its role for plant protection and nutrition where, $S$. platensis enhance zinc levels in tomato. The obtained results emphasize the application of $S$. platensis to enhance the mineral nutrient in plants which are non-polluting, inexpensive, and utilizing renewable resource to maintain the soil fertility. Akkopru and Demir (2005) mentioned that the used Glomus intraradices inhibit FOL at the rate of $17.3 \%$ and enhanced dry root weight effectively, also AlHamoud and Al-Momany, (2015) aimed at determining the efficiency of different vesicular arbuscular mycrrohiza fungi (VAM), symbiotic fungi that interact with the root system of higher plants by producing external and internal hyphae, in improving plant resistance against FOL. The enzymatic activity in the soil is strongly connected to the soil organic matter contents, which provides substrate to support microbial biomass, hence, higher enzyme production by Potassium humate (Yuan and Yue, 2012). Abdel-Monaim et al., (2014) reported that potassium humate, Alga and effective microorganisms significantly increased growth parameters (plant height and number of branches).

Table 4. Effect of tested bioagents and potassium humate on tomato Fusarium wilt disease assessments in vivo under greenhouse conditions during the two successive growing seasons 2014/15 and 2015/16

\begin{tabular}{lccccccccc}
\hline \multirow{2}{*}{ Treatment } & \multirow{2}{*}{ Concentration } & \multicolumn{3}{c}{ Disease severity\% } & \multicolumn{4}{c}{ Disease incidence\% } \\
\cline { 3 - 9 } & & $\mathbf{2 0 1 4 / 1 5}$ & $\mathbf{2 0 1 5 / 1 6}$ & Mean & Ef\% & $\mathbf{2 0 1 4 / 1 5}$ & $\mathbf{2 0 1 5 / 1 6}$ & Mean & Ef\% \\
\hline S. platensis & $5 \%$ & $7.5 \mathrm{~d}$ & $6.2 \mathrm{c}$ & 6.85 & 79.31 & $18.7 \mathrm{c}$ & $12.5 \mathrm{c}$ & 15.60 & 76.22 \\
P. humate & $3 \mathrm{~g} / \mathrm{L}$ & $5.0 \mathrm{e}$ & $5.0 \mathrm{~d}$ & 5.00 & 84.89 & $12.5 \mathrm{~d}$ & $12.5 \mathrm{c}$ & 12.50 & 80.95 \\
B. subtilis & $10^{6} \mathrm{cfu} / \mathrm{mL}$ & $7.5 \mathrm{~d}$ & $6.2 \mathrm{c}$ & 6.85 & 79.31 & $18.7 \mathrm{c}$ & $12.5 \mathrm{c}$ & 15.60 & 76.22 \\
$T$. viride & $10^{5} \mathrm{cfu} / \mathrm{mL}$ & $10.0 \mathrm{c}$ & $11.2 \mathrm{~b}$ & 10.60 & 67.98 & $25.0 \mathrm{~b}$ & $25.0 \mathrm{~b}$ & 25.00 & 61.89 \\
T. harzianum & $10^{5} \mathrm{cfu} / \mathrm{mL}$ & $5.0 \mathrm{e}$ & $5.0 \mathrm{~d}$ & 5.00 & 84.89 & $12.5 \mathrm{~d}$ & $12.5 \mathrm{c}$ & 12.50 & 80.95 \\
Mycorrhiza & $10 \mathrm{~g} / \mathrm{Kg} \mathrm{soil}$ & $11.2 \mathrm{~b}$ & $11.2 \mathrm{~b}$ & 11.20 & 66.16 & $25.0 \mathrm{~b}$ & $25.0 \mathrm{~b}$ & 25.00 & 61.89 \\
Topsin M 70 & $700 \mu \mathrm{g} / \mathrm{L}$ & $1.2 \mathrm{f}$ & $1.3 \mathrm{e}$ & 1.25 & 96.22 & $5.7 \mathrm{e}$ & $5.2 \mathrm{~d}$ & 5.45 & 91.69 \\
Control & & $33.7 \mathrm{a}$ & $32.5 \mathrm{a}$ & 33.10 & 0.00 & $68.7 \mathrm{a}$ & $62.5 \mathrm{a}$ & 65.60 & 0.00 \\
\hline \multicolumn{1}{c}{ LSD at $\mathbf{0 . 0 5}$} & & $\mathbf{0 . 4 6 1}$ & $\mathbf{0 . 5 8 8}$ & & & $\mathbf{0 . 8 7 7}$ & $\mathbf{0 . 6 7 0}$ & & \\
\hline
\end{tabular}

The same letters mean no significant difference $\quad$ Ef\%= Efficacy \%

Effect of tested bioagents and potassium humate on tomato Fusarium wilt disease assessments in vivo under open field conditions

Data in Table 5 indicate that all tested biotic and abiotic treatments recorded high significant difference of Fusarium wilt disease severity and disease incidence $\%$ and the same trend were found in respect of its efficacy. Topsin M70 gave the highest significant reduction in disease severity and disease incidence where, they were 1.0 and $1.07 \%$. Concerning efficacy of treatments, Topsin M70 followed by $T$. harzianum and humate treatment gave the highest efficacy while, mycorrhiza treatment gave lowest one. Abdel-Monaim et al., (2012) evaluated potassium humate to control wilt disease caused by FOL on tomato Super Strain B hybrid. All treatments significantly reduced disease severity and incidence $\%$ as well as, increased plant height, fresh and dry weight of survival plants growing in pots infested with the causal pathogen compared with control. Aghofach et al., (2015) mentioned that the use of extracts of $S$. platensis showed significant effects on the parameters of growth and development of tomato plants, increased the height, diameter compared to control plants. Thus, they can be alternative to the massive use of chemical fertilizers in view of a sustainable agriculture that is friendly to the environment, human and animal health, also Ozgonen et al., (2001) inoculated Glomus etunicatum (GE) in pot experiment and the results indicated that GE increases the growth of tomato plants and could be used against Fusarium wilt of tomatoes. 
Table 5. Effect of tested bioagents and potassium humate on tomato Fusarium wilt disease under field conditions during the growing season 2016/17.

\begin{tabular}{|c|c|c|c|c|c|}
\hline \multirow[b]{2}{*}{ Treatment } & \multirow[b]{2}{*}{ Concentration } & \multicolumn{4}{|c|}{ Disease assessments } \\
\hline & & $\begin{array}{c}\text { Disease } \\
\text { severity \% }\end{array}$ & $\begin{array}{c}\text { Efficacy } \\
\%\end{array}$ & Incidence \% & $\begin{array}{c}\text { Efficacy } \\
\%\end{array}$ \\
\hline S. platensis & $5 \%$ & $3.7 \mathrm{c}$ & 82.7 & $7.4 \mathrm{c}$ & 81.8 \\
\hline Potassium humate & $3 \mathrm{~g} / \mathrm{L}$ & $2.9 \mathrm{~d}$ & 86.4 & $7.3 \mathrm{c}$ & 81.8 \\
\hline B. subtilis & $10^{6} \mathrm{cfu} / \mathrm{mL}$ & $3.7 \mathrm{c}$ & 82.7 & $7.5 \mathrm{c}$ & 81.8 \\
\hline T. harzianum & $10^{5}$ spore $/ \mathrm{mL}$ & $2.9 \mathrm{~d}$ & 86.4 & $7.4 \mathrm{c}$ & 81.8 \\
\hline Mycorrhiza & $10 \mathrm{~g} / \mathrm{kg}$ soil & $5.1 \mathrm{~b}$ & 76.1 & $11.1 \mathrm{~b}$ & 72.7 \\
\hline Topsin M70 & $700 \mu \mathrm{g} / \mathrm{L}$ & 1.0 & 95.3 & $1.07 \mathrm{~d}$ & 97.4 \\
\hline Control & & $21.4 \mathrm{a}$ & & $40.7 \mathrm{a}$ & \\
\hline LSD at 0.05 & & 0.586 & & 0.510 & \\
\hline
\end{tabular}

The same letters mean no significant difference

Effect of tested bioagents and potassium humate on some vegetative parameters of treated tomato which naturally infected with fusarium wilt disease in vivo under greenhouse conditions

Data in Table 6 reveal that treatments i.e., Topsin M70 (700 $\mu \mathrm{g} / \mathrm{L}), \quad T$. harzianum $\left(10^{5}\right.$ spore $\left./ \mathrm{mL}\right)$, potassium humate $(3 \mathrm{~g} / \mathrm{L})$, B. subtilis $\left(10^{6} \mathrm{cfu} / \mathrm{mL}\right)$, and mycrrohyiza $(10 \mathrm{~g} / \mathrm{kg}$ soil) had a great positive effect on some vegetative parameters of tomato plants which naturally infected with FOL under open field conditions comparing with control treatment. In this respect, Topsin M70 treatment recorded the highest significant fresh and dry weight/plant, and length of the plant $(430.0 \mathrm{~g}, 60.0 \mathrm{~g}$ and $75.0 \mathrm{~cm})$, respectively, followed by $T$. harzianum treatment $(422.0 \mathrm{~g}, \quad 51.0 \mathrm{~g}$ and $72.0 \mathrm{~cm})$, respectively. Meanwhile, potassium humate treatment recorded $415.0 \mathrm{~g}, 50.0 \mathrm{~g}$ and $71 \mathrm{~cm}$ of the three parameters respectively, followed by $B$. subtilis which recorded $395.0 \mathrm{~g}, 45.0 \mathrm{~g}$ and $69.0 \mathrm{~cm}$ respectively. On the other hand, alga (S. platensis) recorded $265.0 \mathrm{~g}, 32.0$ $\mathrm{g}$ and $32.0 \mathrm{~cm}$ respectively and mycorrhiza recorded the lowest vegetative parameters (195.0 g, $20.0 \mathrm{~g}$ and $66.0 \mathrm{~cm})$. Generally, all treatments increased the studied vegetative parameters of the tomato plants. In this respect, Aghofach et al., (2015) mentioned that the use of extracts or powder of S. platensis showed significant effects on growth parameters and development of tomato plants and increased the height, diameter, biomass of aerial parts, as well as the number of fruits compared to control plants. The aqueous extract and powder of S.platensis were the most effective in improving tomato plant growth and development parameters. Thus, they can be alternative to the passive use of chemical fertilizers in view of a sustainable agriculture that is friendly to the environment, human and animal health. Ozgonen et al., (2001) inoculate Glomus etunicatum (GE) in pot experiment. GE was found to be able to increase the weight of the dry plant, length of the shoot and root irrespective whether FOL infected the tomato plants or not. Colonization the roots by GE was determined to be $62.3 \%$ when the FOL as absent and as $53.2 \%$ when the plants were infected. Results indicate that GE increases the growth of tomato plants and could be used against Fusarium oxysporum f.sp. lycopersici wilt of tomatoes. Nikitas et al., (2002) reported that mycorrhiza treatment increased fresh and dry weight as well as mean plant height in tomatoes by 96,144 and $21 \%$ compared to the controls. Abdel-Monaim et al., (2014) reported that potassium humate, alga and effective microorganisms significantly increased growth parameters (plant height and number of branches). Abdel-Monaim et al., (2012) evaluated potassium humate for controlling wilt disease caused by Fusarium oxysporum f.sp. lycopersici on Super Strain B hybrid, all treatments significantly increased plant height, fresh and dry weight of survival plants growing in pots infested with the causal pathogen compared with control.

Table 6. Effect of tested bioagents and potassium humate on some vegetative parameters of treated and naturally infected tomato plants with Fusarium wilt disease in vivo under greenhouse conditions during the growing season 2015-2016.

\begin{tabular}{lcccc}
\hline Treatment & Concentration & $\begin{array}{c}\text { Fresh weight } \\
(\mathbf{g})\end{array}$ & $\begin{array}{c}\text { Dry weight } \\
(\mathbf{g})\end{array}$ & $\begin{array}{c}\text { Plant } \\
\text { length(cm) }\end{array}$ \\
\hline S.platensis & $\mathbf{5 \%}$ & $265 \mathrm{c}$ & $32 \mathrm{~d}$ & $66.5 \mathrm{bc}$ \\
Potassium humate & $3 \mathrm{~g} / \mathrm{L}$ & $415 \mathrm{ab}$ & $50 \mathrm{bc}$ & $71.0 \mathrm{abc}$ \\
B.subtilis & $10^{6} \mathrm{cfu} / \mathrm{ml}$ & $395 \mathrm{~b}$ & $45 \mathrm{c}$ & $69.0 \mathrm{bc}$ \\
T. harzianum & $10^{5} \mathrm{cfu} / \mathrm{ml}$ & $422 \mathrm{a}$ & $51 \mathrm{~b}$ & $72.0 \mathrm{ab}$ \\
Mycorrhiza & $10 \mathrm{gr} / \mathrm{kg} \mathrm{soil}$ & $195 \mathrm{~d}$ & $20 \mathrm{e}$ & $66.0 \mathrm{c}$ \\
Topsin M70 & $700 \mu \mathrm{g} / \mathrm{L}$ & $430 \mathrm{a}$ & $60 \mathrm{a}$ & $75.0 \mathrm{a}$ \\
Control & & $127.7 \mathrm{e}$ & $7.7 \mathrm{f}$ & $34.7 \mathrm{~d}$ \\
\hline LSD at $\mathbf{0 . 0 5}$ & & 21.414 & 5.796 & 5.851 \\
\hline
\end{tabular}


Effect of tested bioagents and potassium humate on some bio-constituent contents of treated tomato and naturally infected with Fusarium wilt disease in vivo under field conditions

Data in Table (7) indicate that all treatments decreased hydrolyzing enzymes activities (PG and $\mathrm{CX})$ compared with the control treatment. In this respect, Topsin M70 treatment most effective treatment in reducing the activity of $\mathrm{PG}$ and $\mathrm{CX}$ enzymes $(6.4,8.3 \%)$, respectively, followed by potassium humate treatment which recorded 15.4 , $09.3 \%$, respectively, then $T$. harzianum $(17.3,18$. $5 \%$ ). On the other hand, mycorrhiza was the least effective treatment in reducing the activity of PG and CX enzymes where the recorded activities \% were $36.5,28.8 \%$ respectively. In this respect, Dwivedi and Singh (2015) reported that Fusarium oxysporum f. sp. lycopersici produced cellulolytic enzyme that increased with the increase in age of the culture. Retig and Chet, (1974), reported that activities of polygalacturonase and cellulase increased in catechol - treated and resistant tomato plants. After inoculation with Fusarium oxysporum f. sp. lycopersici race 2. The catechol- treated and resistant plants remained symptomless, while susceptible plants developed symptoms of disease. It is therefore suggested that increased activity of cell wall degrading enzymes in inoculated plants does not necessary cause the development of disease symptoms.

Data in the same table indicate that, all treatments affected generally the content of phenols comparing with the control treatment. Potassium humate, $T$. harzianum and $B$. Subtilis recorded the highest content of total phenols $(5.389,5.372,5.217 \mathrm{mg} / \mathrm{g})$, respectively. However, mycorrhiza recorded the lowest content of total phenols $(3.555 \mathrm{mg} / \mathrm{g})$. Mohd et al., (2012) considered the high content of phenols is a good indicator of defense mechanisms in treated plants with T. harzianum.

Table 7. Effect of tested bioagents and potassium humate on some bio-constituent contents of treated tomato and naturally infected with Fusarium wilt disease under greenhouse conditions during the growing season 2015-2016.

\begin{tabular}{lcccccc}
\hline \multirow{2}{*}{ Treatment } & Concentration & Enzyme activity $(\%)$ & \multicolumn{2}{c}{ Phenolic contents (mg/50g) } \\
\cline { 3 - 7 } & & $* \mathbf{P G}$ & $* * \mathbf{C X}$ & $\begin{array}{c}\text { Free } \\
\text { phenols }\end{array}$ & $\begin{array}{c}\text { Conj. } \\
\text { phenols }\end{array}$ & $\begin{array}{c}\text { Total } \\
\text { Phenols }\end{array}$ \\
\hline S. platensis & $5 \%$ & 25.0 & 23.0 & 0.402 & 3.377 & 4.779 \\
P. humate & $3 \mathrm{~g} / \mathrm{L}$ & 15.4 & 09.3 & 0.652 & 4.737 & 5.389 \\
B. subtilis & $10^{6} \mathrm{cfu} / \mathrm{mL}$ & 24.9 & 24.7 & 0.953 & 4.264 & 5.217 \\
T. viride & $10^{5} \mathrm{cfu} / \mathrm{mL}$ & 29.1 & 26.8 & 0.552 & 4.187 & 4.739 \\
T. harizanum & $10^{5} \mathrm{cfu} / \mathrm{mL}$ & 17.3 & 18.5 & 0.961 & 4.411 & 5.372 \\
Mycorrhiza & $10 \mathrm{~g} / \mathrm{kg} \mathrm{soil}$ & 36.5 & 28.8 & 0.377 & 3.178 & 3.555 \\
Topsin M70 & $700 \mu \mathrm{g} / \mathrm{L}$ & 6.4 & 8.3 & 0.599 & 4.871 & 5.470 \\
\hline Control & & 76.0 & 62.2 & 0.368 & 2.860 & 3.228 \\
\hline
\end{tabular}

$* \mathrm{PG}=$ Polygalacturonase

$* * \mathrm{Cx}=$ Cellulase

\section{References}

Abd-Alla, M.A.; El-Mohamedy, R.S. and ElMougy, N.S. (2007). Control of sour rot disease of lime fruits using saprophytic isolates of yeast. Egypt. J. Phytopathol, 35(2): 39-51.

Abdel-Kader, M.M.; El-Mougy, N.S. and Lashin, S.M. (2012). Integration of biological and fungicidal alternatives for controlling foliar diseases of vegetables under greenhouse conditions. Int. J. of Agric. Forestry, 2(2):38-48.

Abdel-Monaim, M.F.; Abdel-Gaid, M.A. and ElMorsy, M.E.A. (2012). Efficacy of rhizobacteria and humic acid for controlling fusarium wilt disease and improvement of plant growth, quantitative and qualitative parameters in tomato. Sci. J. of Plant Pathology, 1: 39-48.

Abdel-Monaim, M.F.; Abdel-Gaid, M.A. and Zayan, S.A. (2014). Effective of organic compounds in controlling root rot/wilt disease, growth and yield parameters of pepper.
International Journal of Agricultural Sciences ,4(4): 143-150.

Agbevin, N.O.; Emechebe, A.M. and Marley, P.S. (2004). Evaluating of neem seed powder for fusarium wilt and meloidogyne control on tomato. Archieves of Phytopathology and Plant Protection, 37(4): 319-326.

Aghofach, N.; Schinzounka, P.A. and Tatchago, V. (2015). Effect of extracts or powder of Jatropha curces and Spirulina platensis on the growth and development of tomato plant. Journal of Applied Biosciences, 90: 8413-8420.

Akkopru, A. and Demir, S. (2005). Biological control of fusarium wilt in tomato causing by Fusarium oxysporum f.sp. lycopersici by AMF Glomus intraradices and some rhizobacteria. Journal of Phytopathology, 1: 544-550.

Akram, W.; Anjum, T. and Ahmad, A. (2014). Basal susceptibility of tomato varieties against different isolates of Fusarium oxysporum f. sp. lycopersici. International J. Agric. \& Biology, 16(1):171-176. 
Al-Hamoud, G. and Al-Momany, A. (2015). Effect of four mycorrhiza products on fusarium root rot on different vegetable crops. Plant Pathology and Microbiology, 6(2).

http://dx.doi.org/10.4172/2157-7471.1000255

Alwathnani, H.A. and Perveen, K. (2012). Biocontrol of fusarium wilt of tomato by antagonist fungi and cyanobacteria. African J. Biotechnology, 11(5): 1100-1105.

Amini, J. (2009). Physiological race of $F$. oxysporum f.sp. lycopersici in Kurdistan province of Iran and reaction of some tomato cultivar to race 1 of pathogen. Plant Pathology Journal, 8: 68-73.

Aneja, K.K. (2001). Experiments in microbiology plant pathology tissue culture mushroom production technology. $3^{\text {rd }}$. Ed. 468pp.

Barari, H. (2016). Biocontrol of tomato fusarium wilt by Trichoderma species under in vitro and in vivo conditions. Cerceton Agronomice in Maddova XLIX, (1):91-98.

Barnett, H.L. and Hunter, B.B. (1998): Illustrated Genera of Imperfect Fungi, 4 ${ }^{\text {th }}$ Ed., 218 pp., APS Press, St. Paul, MN., USA.

Cotxarrena, L.; Trillas, M.I.G.; Steinberg, C. and Alabou V.C. (2002). Use of sewage-sludge compost and Trichoderma asperellum isolates to suppress fusarium wilt of tomato. Soil Biology and Biochemistry, 34: 467-476.

Gomez, K.A., Gomez, A.A. (1984). Statistical procedures for agricultural research, $2^{\text {nd }}$ ed. John Wiley and Sonsltd., New York, - 680 pp.

Hirano, Y. and Arie, T. (2006). PCR-based differentiation of Fusarium oxysporum f.sp. lycopersici and radicis-lycopersici and races of $F$. oxysporum f. sp. lycopersici. Journal of General Plant Pathology, 72(5): 273-283.

Katan, T.; Zamir, D.; Sarfatti, M. and Katan, J. (1991). Vegetative compatibility groups and sub groups in Fusarium oxysporum f.sp. lycopersici. Phytopathology, 81: 255-262.

Layam, A.; Gannavora, P.B. and Pilla, K. (2016). Effect of supplementation of Spirulina platensis to enhance the zinc status in plants of Amaranthus gangeticus, Phasealus aurens and tomato. Journal of Bcteriology and Parasitology, 7(6): 289-299.

Mohamed, A. and Zohreh, Y. (2015). Biological control of fusarium wilt of tomato (Solanum lycopersicum) by Trichoderma spp. as antagonist fungi. Biological Forum International Journal, 7(1):887-892.

Mohammed, A.S.; Kadar, N.H.; Kihal, M.; Henni, J.E.; Sanchez, J.; Gallego, E. and GarridoCardenas, J.A. (2016). Characterization of Fusarium oxysporum isolates from tomato plants in Algeria. African Journal of Microbiology Research, 10(30): 1156-1163.

Mohd, R.; Biswas, S.K. and Shiv, S. (2012). Biochemical basis of defense response in plant against fusarium wilt through bio-agents as an inducer. African journal of Agricultural research, 7(43): 5849-5857.

Moliszewska, E. and Pisarek, I. (1996). Influence of humic substances on the growth of two phytopathogenic soil fungi. Environmental International, 22: 579-584.

Narendra, K. and Swati, S. (2015). Fusarium wilt of Solanum lycopersicum L. (Tomato) at Panchgaon. Int. J. Curr. Microbiol. App. Sci., 4(11): 253-260.

Nelson, E.; Toussoum, T.A. and Marasas, W. (1983). Fusarium species: an illustrated manual for identification Pennsylvania State University Press, University Park.

Nikitas, K.; Fotios, B. and Nikalaos, S. (2002). Effect of verticillium wilt (Verticillium dahilae Kleb.) and mycorrhiza (Glomus mosseae) on root colonization growth and nutrient uptake in tomato and eggplant seedlings. Scientia Horticulturae, 94: $145-156$.

Ozgonen, H.; Bicici, M. and Erkilic, A. (2001). The effects of salicylic acid and endo mycorrhiza fungus Glomus etunicatum on plant development of tomatoes and fusarium wilt caused by Fusarium oxysporum f.sp. lycopersici. Turk J. Agric. For, 25: 25-29.

Priyanka, M.; Pooja S. and Tripathi N.N. (2014). Evaluation of plant extracts against Fusarium oxysporum f. sp. lycopersici, wilt pathogen of tomato. Research Journal of Microbiology, 9: 129-134.

Retig, N. and Chet, I. (1974). Catechol induced resistance of tomato plants to fusarium wilt. Physiological Plant Pathology, 4(4): 469-472.

Selim, M.E. and Zanaty, F.M. (2014). Discrimination of different pathogenic Fusarium oxysporum isolates based on virulence and intergenomic-spacer sequences (IGS). Int. J. Curr. Microbiol. App. Sci., 3(11): 157-165.

Singh, U.P. and Prithiviraj, B. (1997). Neemazol, product of neem (Azadirachta indica) induces resistance in pea (Pisum sativum) against Erysiphe. African Journal of Microbiology Research, 5(27): 4937-4945.

Sirirat, S.; Rungprom, W. and Sawatdikorn, S. (2009). Antifungal activity of essential oils derived from some medicinal plants against grey mould (Botrytis cinerea). As. J. Food Ag- Ind., Special Issue, S 229-233.

Sultana, N. and Ghaffar, A. (2013). Effect of fungicides, microbial antagonists and oil cakes in the control of Fusarium oxysporum, the cause of seed rot and root infection of bottle gourd and cucumber. Pak. J. Bot., 45(6): 2149-2156.

Dwivedi, S.K. and Singh, E. (2015). In vitro cellulase activity of two wilt causing soil fusaria (F. solani and Fusarium oxysporum f.sp. lycopersici) and efficacy of some pesticides 
against the soil fusaria. Journal of Applied Horticulture, 17(1): 58-65.

Xiao, C.L. and Subbarao, K.V. (1998). Relationships between Verticillium dahliae inoculum density and wilt incidence, severity, and growth of cauliflower. Phytopathology, 88(10):1108-1115.

Yuan, B. and Yue, D. (2012). Soil microbial and enzymatic activities across a chrono sequence of Chinese Pine plantation development on the Loess Plateau of China. Pedosphere, 22(1):1-12.

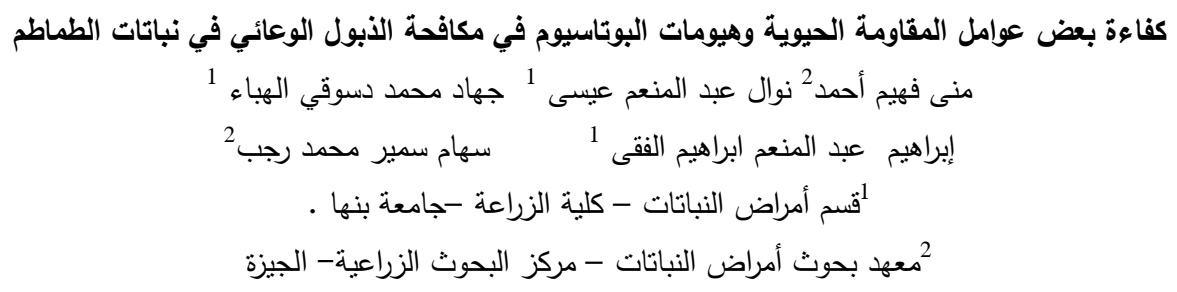

تصاب نباتات الطماطم في الحقل والصوبة بالعديد من الأمراض ويعتبر فطر Fusarium oxysporum من أهم الفطريات التي

تسبب الذبول الوعائى على نباتات الطماطم وقد نم استخدام بعض عوامل المقاومة الحيوية وهيومات البوتاسيوم لمكافحة مرض الذبول الوعائي في نباتات الطماطم. وأوضحت النتائج أن كلا من Trichoderma harzianum يليه Trichoderma viride ، Bacillus subtilis هي أفضات الفضل

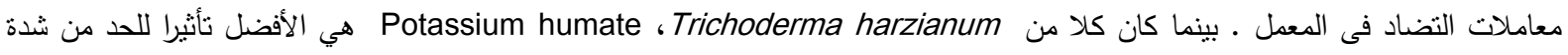
الإصابة يليها في ذلك المعاملة ببكتيريا Bacillus subtilis والطحلب وذلك تحت ظروف الحقل والصوبة. ومن ناحية أخرى كانت الميكوريزا الأقل تأثيرا تحت ظروف الحقل والصوبة.

كما أوضحت النتائج ان هذه المواد الحيوية المختبرة كان لها تأثيرا فعال على Fusarium oxysporum حيث أدت إلى نتاقص التص

الإنزيمات المحللة بينما أدت أيضا إلى زيادة نسبة الفينولات ـ ومن جهة أخرى كان لها تأثيرا أخر فعال على نباتات الطماطم حيث إنها أدت لزيادة

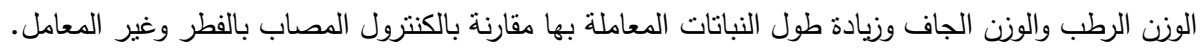

